Copyright (C) 2014 by Academic Publishing House Researcher



Published in the Russian Federation

European Researcher

Has been issued since 2010.

ISSN 2219-8229

E-ISSN 2224-0136

Vol. 85, No. 10-2, pp. 1843-1857, 2014

DOI: $10.13187 /$ er.2014.85.1843

www.erjournal.ru

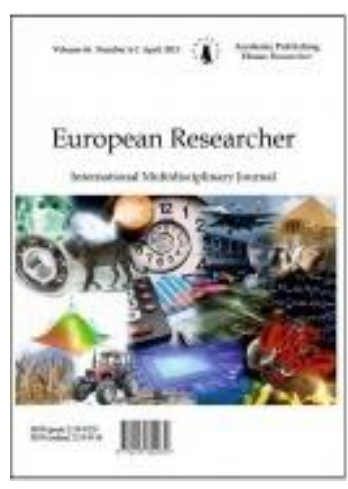

UDC 336.02

\title{
The Association of Russian Banks (ARB) and Banking Community: the Practice and Prospects of Cooperation
}

\author{
Vitaly F. Ershov \\ Moscow State Regional University, Russian Federation \\ Radio street 10a, Moscow 105005 \\ Dr. (History), Professor \\ E-mail: ershov_vf@mail.ru
}

\section{Abstract}

The article discusses the peculiarity of the formation and basic directions of activities of the Association of Russian Banks (ARB) as the leading corporate establishment of domestic financial business. ARB consistently provides innovative projects aimed at improving the native system of credit agencies, the development of their interaction with the state, developing the ties with the international financial institutions.

Keywords: The Association of Russian Banks; corporate culture; financial business; credit policy; national banking system of Russia.

\section{Introduction}

The relevance of the topic due to the theoretical and practical need of Russian economic science and society in the study of the institutional experience of the innovative construction of the banking community in the context of contemporary policies of modernization of Russia.

\section{Materials and Methods}

The article used the documents of the Association of Russian Banks, the materials corporate forums and business press. The research is carried out on the basis of General scientific and special, economic, historical and sociological technology research.

\section{Discussion}

Present-day Russia features the constantly growing role of the banking sector, which is becoming a significant factor of the innovative development of economy and business. It significantly influences the development and improvement of the society's social structure. In addition, the role of the state, which conducts the organizational and regulatory functions in the financial sphere, thus providing the increase of its qualitative and quantitative features, is also increasing.

The Association of Russian Banks (ARB) is acting as integrator uniting the system of native credit establishments strategically aimed at promoting the process of developing in the Russian 
Federation the effective, institutionalized and innovative national banking system. ARB creates the new social look of the banking system, introduces positive corporate culture in the banking society.

The developing constructive dialog between the state and financial business-structures has become an important factor in the development of the native banking system: due to the positive interaction between the state controlling authorities and management of the banking sphere and financial business-structures, the perspective projects are approved and implemented, the financing of the innovative axes of R\&D is improved and the business banking culture is enhanced.

On 12 December 2013, President of Russia V.V.Putin in the annual Message of President of the Russian Federation to the Federal Assembly of the Russian Federation stressed the importance of conducting consistent activities to improve the investment situation in the Russian Federation: 'Two years ago in cooperation with the business-society we started the systematic work on the improvement of the business climate in Russia. Thus, in the next year we will launch the national rating of the business climate state in the regions of Russia' [1. P. 4]. President of Russia V.V.Putin also stressed that for further successful development of the business it is necessary to achieve the high level of its transparency, strict observance of the law including the banking organizations, which significantly determine the successful innovative development of economy and industry.

President of Russia V.V.Putin has repeatedly noted the importance of the strengthening of the national banking system potential, institutions of the development and stock market, necessity of implementing the strategic infrastructural projects in the financial sector of economy: 'The ups and downs in the global financial markets have taught us: our modernization must be financed, first of all, by us... To take a decision on increasing the opportunities of investing the national assets. We will develop the national banking system to provide the increase of the availability of the credit for the real sector and the decrease of the rates'[2].

Prime Minister of Russia D.A.Medvedev in his activities pays significant attention to the development of the banking system and financial sector of the country in the context of the industry and business modernization and implementation of the innovative technologies. On 28 November 2013, D.A.Medvedev conducted a special meeting dealing with the perspective of the development of the Russian banking system. The main objectives in the area included the increase of the transparency in the work of the credit establishments; in addition, from 1 January 2014 the new requirements to the identification of the banks capitals and minimal standards of its reasonableness were introduced. According to head of the government, these measures must provide the additional stability to the financial system of the country. In addition, D.A.Medvedev has reminded about the document developed by the Cabinet of Ministers to increase the effectiveness of the mechanisms of the deposits insurance: 'I will mention that the draft law aimed at improving the system of the deposits insurance, provides the differentiation of the banks' payments to the system. It is suggested to move to the more differential model according to the risk level, respectively, this must also add the stability and avoid the actions, which endanger the stability of the system taking into account that for one's actions, respectively, risks will be paid by ruble'[3].

The United Russia party in the program documents stresses the importance for the successful implementation of the project of modernizing the Russian economy and society the development of the banking sector, which is to provide the financial support of the business (including large, medium and small), introduction of the technological innovations in the production, R\&D and development of the venture capital. In addition, the interbank cooperation, development of the cutting-edge financial infrastructure, constructive activities of the banking social corporate establishments is becoming a significant factor in the development of the native banking system, as well as contributing to the improvement of the investment climate.

At present, the banking system of Russia is at the stage of transformation, which strategically aims at developing the modernized financial sphere of modern type corresponding to the world quality standards [4. P. 5].

In the context of developing the new banking business culture of the modernization social and economic transit period the Russian Federation began to feature the professional corporate organizations of the Russian banking business-society including the one with the one of the leading places - the Association of Russian Banks (ARB) aimed at the world improvement of the native financial sphere, development of the banking world as an important integral part of the institutionalized business and economy system. 
The development of the new-type banking structures focused on the financial activities within the market liberal economy has been in the late period of the existence of the soviet system, when the Perestroika ideas in the business sphere and public sector have begun to dominate changing the very structure of the economic system. In August 1989, the USSR established the Moscow banking Union, which was one of the first corporate public organizations of the Russian banking businesses. In 1990, the native financial society established the Russian Banking Union with headquarters in Perm. On 27-28 March 1991, Moscow hosted the Meeting of the commercial and cooperate banks of RSFSR conducted on the initiative of the Moscow Banking Union and Leningrad Association of Banks, which decided to re-organize the Russian Banking Union into a new structure - the Association of Russian Banks (ARB). By the moment of its establishment, ARB has united 65 commercial and corporate banks. It also included the leading audit companies Interbank Financial House, Moscow Audit Chamber, International Center for Taxation, as well as the Russian subdivisions of the international companies - Arthur Andersen, Deloyt and Tush, etc.

The special importance for the development of the new Russian business world had the fact that ARB acted as its significant backbone factor having become the leading institutional basis of the native banking society. The Association of Russian Banks has united more than $75 \%$ of the banking institutions, which included more than $90 \%$ of the joint capital of the acting financial organizations, as well as about $90 \%$ of all assets of the native banking system.

At present, ARB involves 713 members including 507 credit organizations. The total number, taking into account the associated members, of ARB participants includes 952 establishments, including 615 financial and credit organizations. The Association of Russian Banks in its program and activities expresses the interests of the native banks of wide spectrum: ARB includes 30 leading Russian banks featuring the large proportion of the capital and medium and small banks featuring significantly fewer assets. About $15 \%$ of the banks involved in ARB feature the registered capital within $30 \mathrm{mln}$ rubles, and at the same time $51 \%$ of the banks features the registered capital from 30 to 300 mln rubles.

On 19 December 2013, the Association of Russian Banks included new participants: Dzhast Bank LLC (Moscow), Tikhookeansky Vneshtorgbank JSC (Yuzhno-Sakhalinsk), Konnekt LLC (Vladimir), Zeb/Rolphes.Shyrenbek.Associates LLC (Kiev, Ukrain), rep office of Popolare di Vitsentsa - Socheta cooperativa per atsone (Moscow, Italy), subdivision of the Expirian CIF Limited company (Moscow), Sapient Naitro LLC (Moscow). Thus, from the moment of its establishment the Association of Russian Banks has accumulated the significant financial resources. Their total capital is equal to 470 bln rubles.

The Association of Russian Banks also includes the banks with foreign participation in the registered capital or those under the complete foreign control, This extends the types' spectrum of the credit organizations acting in the Russian financial world. Among the banks involved in the ARB structure, 36 of them have the 100-\% foreign capital and 10 banks - more than $50-\%$ foreign capital. The Association of Russian Banks also included many of the foreign banks, including the leading ones ABN AMRO bank, Societe Generale - East, Austria's bank, Chase Manhattan bank International, China's Bank, etc. In 1995, the amount of the membership fees of the ARB participants was from 4 to 16 bln rubles (depending on the amount of the paid equity fund).

The Association of Russian Banks includes all participants of the Big Auditing Four, as well as 13 rep offices of the leading foreign banks. The factor of taking into account the peculiar social and economic conditions being the place of the development of the native banking sector significantly influences the effectiveness of the operation of the Russian banking system [5. P. 87].

Due to the consistent activities of ARB the process of instituting the native financial sector has been intensified: the Association of Russian Banks acted as founder or co-founder of the Moscow Interbank Exchange Market (MIEM), National Association of Participants of the Mortgage Market, Moscow Clearing Center, National Bureau of Credit Histories and other banking and financial structures.

ARB is a member of co-founders of the Moscow Interbank Exchange Market, Interbank Center of Management Issues Fund, Moscow Clearing Center, Institute of ARB Banking, International Moscow Financial and Banking School, Center of the Information Support of Banking and Business of ISISS RAS, Club of Heads of the Banking Services on Public Relations and Advertising, the Blago non-state pension fund. 
The supreme control body of the Association of Russian Banks is the Congress, which is considering the necessary issues of its organization and activities.

The exclusive competence of ARB includes:

- the right for making amendments to the Association's Charter;

- the approval of the new Charter;

- taking the decision on the re-organization and elimination of the Association;

- electing President, members of the Assembly and members of the Revision

Commission of the Association, early termination of their powers;

- the approval of the annual report of the Association;

- defining the principles of developing and using the property of the Association;

- considering the statements of the members on the appeal against the Assembly's

decision to exclude them from the Association.

President of ARB or (on his order) one of Vice Presidents of the Association governs the Assembly. Between the sessions of the Assembly, the supreme management body over the Association is the Council, which solves the current organizational and information issues, provides the interbank cooperation and etc. The ARB Council is formed from the candidates proposed by the Association's members, as well as the included in it in accordance with the post heads of regional banking associations - members of the All-Russian council of the regional banking associations. The re-election of the Council members is conducted each 5 years. President of ARB is in charge of the Council. Between the sessions of the Council, the issues connected with the competence and activities of ARB are solved by the Presidium of the Council headed by President of ARB. The issues connected with financial and economic, information or any other activity of ARB, which is not included to the exclusive competence of other management bodies of the Association are solved by the Board, which is the permanently acting collegial executive body of the Association of Russian Banks and is accountable to the Assembly and Council.

The Board of ARB is headed by President of the Association and involves executive Vice presidents, Financial Director and etc., including heads of specialized working bodies of ARB. Heads of structural subdivisions of the ARB Board can participate in the sessions of the Board with the right of advisory vote.

President of ARB is elected by the Assembly for a 5-year term and has the one-man executive power, represents the interests of the Association in relations with legal entities and individuals both in the Russian Federation and abroad, concludes the contracts and agreements with the native and foreign business partners, conducts the supreme management over the organization, defines its perspective policy, principles of the relations with the state authorities and other corporate public organizations.

The organizational structure of ARB includes the following committees and working groups:

- The Committee on the monetary policy and banking supervision

- The Committee on the banking law and legal precedents

- The Committee on the payment systems and settlements organization

- The Committee on the international activities

- The Committee on the mortgage crediting

- The Committee on the information policy and public relations

- The Committee on the information and Internet technologies

- The Committee on the AML/ TF and compliance risks

- The Committee on the information security

- The Committee on the development of the time market

- The Committee on the precious metals

- The Coordination Committee on the quality standards of banking activities

- The Committee on the evaluation activity

- The Committee on the development of the financial and credit mechanism of the small and medium business

- The Committee on the personnel policy

- The Committee on the Basel II standards and risks management

- The working group on the improvement of the legislation on the enforcement proceeding 

vehicles

- The working group on the development of the mechanism of accounting the pledged

- The working group on the preparation of proposals on the establishment of interaction of the banks - members of ARB operating in the market of the precious metals

- The working group on the improvement of the legislation on the mortgage

- The working group on the improvement of the currency legislation

- The working group on the improvement of the legislative and regulatory base of the organization of the letter of credit payment method

- The expert and methodical center of the banking security at the Association of Russian Banks

The effective form of organizing the activities of the expert society of the banking world, dialog between heads of the banks and state authorities controlling the native banking system are the permanent ARB assemblies, which discuss the problems and perspectives of the Russian banking sector development. On the XVI ARB Assembly the Strategy of increasing the competitiveness of the national banking system has been adopted.

On 3 April 2013, Moscow, the Pillar hall of Unions hosted the XXIV Assembly of the Association of Russian Banks with more than 1000 participants including the delegates and guests. The agenda of the Assembly was Banks and society: the role of the credit organizations in the social and economic development of Russia [6]. The Assembly along with the generally social issued discussed a lot of important issues of the applied activities of the credit organizations, particularly, connected with increasing the requirements on the booking.

On 2 April 2014, Moscow, the Pillar hall of Unions hosted the XXV Assembly of the Association of Russian Banks aimed at discussing the project on the perspectives of the banking system of Russia: a view of the banking community. The reports were presented by ARB President G.A.Tosunyan and Chairperson of the Bank of Russia E.S.Nabiullina, as well as by many representatives of the system of the state authorities of Russian and banking community: heads and representatives of the Federal Assembly of the Russian Federation, Russia's Government, ministries and agencies, bankers and financial experts, academics, members of the international financial institutions. The ARB Assembly stressed that at present the banking system of the country has become one of the main driving forces of the native economy and the most important factor of its consistent and dynamic development. The banking system of Russia also faces the new goals: modernization institutional reforms, improvement of the banking service quality, entering the international financial market [7].

The Association of Russian Banks has been always conducting the meaningful interaction with the state authorities and business - management of the Russian Federation in the field of financial and credit policy and investment development, providing the expert support to many state structures dealing with the development and implementation of the cutting-edge innovative financial programs. At present, the importance of the banking system for the development and improvement of the real sector of economy is constantly growing, respectively, the role of the state management of the financial sphere of economy and business is also increasing [8].

On 16 December 2012, the Association of Russian Banks held the session of the Public and consultative council on the establishment and interaction of the Moscow Government with the native banks.

The ARB activities significantly influence the development by the state authorities and heads of the leading banking structures the inter-Russian financial policy: the ARB structure includes 23 committees, 1 section and 6 working groups dealing with the R\&D works on the major axes of the banking business [9. P. 25].

On 20 December 2013, the Federation Council of the Russian Federation conducted the session of the Inter-regional banking council at FC CF of the Russian Federation held by Chairperson of the Federation Council V.Matviyenko on the topic: the improvement of the legislation to prevent criminal risks in the banking activities as a condition for the effective development of economy and social sphere [10. P. 15].

The Association of Russian Banks relying on the conducted R\&D and expert work, presented perspective financial and credit innovative projects to the authorities of the Russian Federation: the Federal Assembly of the Russian Federation, Central bank, state expert commissions and etc. 
[11. P. 227-228]. In particular, the scientific developments on the improvement of the national payment system of Russia prepared by the financial specialists of ARB have been used by the Bank of Russia during the modernization of the native payment system in the context of implementing the technological innovations and improving the level of its security [12].

A significant direction in the activities of the Association of Russian Banks is the legal protection and representation of the business-interests of the financial organizations in the state authorities of the Russian Federation, state structures managing the financial sector of the country - the Central Bank of Russia, parliamentary commissions, state authorities for controlling the banking sector, structures of the perspective state planning of the economy and business development, as well as legal law-enforcement and tax structures dealing with the development and implementation of the banking financial and credit policy. The organizational, $\mathrm{R} \& \mathrm{D}$, expert and information activities of ARB have intensified the dialog between the state authorities and banking community, thus creating favorable conditions for improving the investment climate, implementing the cutting-edge financial technologies and extending the state and private partnership in the banking sphere.

On 23 December 2013, Executive Vice President of ARB V.Kiyevsky participated in the meeting of the heads of a number of the native banks - market leaders in consumer crediting, with Chairperson of the Bank of Russia Elvira Nabibullina. The meeting discussed the perspectives of developing the consumer credit technologies in the Russian Federation. The session included 11 heads and their deputies of 7 banks: OTP Bank JSC, KhKF Bank LLC, TKS Bank (ZAO), Svyaznoy Bank (ZAO), IKB Sovkombank LLC, KB Renessans Kredit LLC, Bank Russky Standart (ZAO). During the meeting, Elvira Nabibullina stressed that already for a year the Russian banks have been working in the conditions when the Central Bank of the Russian Federation with the help of booking and other mechanisms regulates the consumer market in the direction of its 'cooling' [13]. The adopted Federal Law on the consumer credit, which will enter into force since 1 July 2014, will also make particular corrections into the banks' activities specializing in the consumer crediting. The meeting included first deputies and deputies of Chairperson of the Bank of Russia A.Yu.Simanovsky, K.V.Yudayeva and M.I.Sukhov, as well as Director of the Banking Regulation Department A.A.Lobanov [13].

The ARB Board conducts meaningful cooperation with the Central Bank of Russia, regularly participating in the meeting with its Chairperson Elvira Nabibullina. On 7 November 2013, on the initiative of ARB the meeting of heads of the banks with the management of the Bank of Russia was held. The participants were discussing the issues of regulating the activities of the credit organizations by the Bank of Russia, particularly, the adoption of the law on the consumer credit, implementation of the Provision of the Bank of Russia No.254-П on the development by the credit organizations of the reserve for possible losses on loans and similar debts, on the transition to Basel III and possible differential approach on the payments to the deposits insurance system. The reports on these issues were presented by Chairperson of the State Duma Committee on Financial Markets Natalya Burykina and First Deputy Chairperson of the Bank of Russia Alexey Simanovsky. During the meeting the following persons addressed their reports to heads and specialists of the credit organizations, as well as participated in the discussion: Deputy Chairperson of the Bank of Russia - Director of the Legal Department Sergey Golubev, Director of the Banking Regulation Department of the Bank of Russia Vasily Pozdyshev, Director of the Monetary and Credit Policy Department of the Bank of Russia Igor Dmitriyev, Director of the National Payment System Department of the Bank of Russia Timur Batyrev, Deputy Director of the Accounting and Reporting Department of the Bank of Russia Vladimir Volkov, Deputy Director of the Banking Supervision Department of the Bank of Russia Olga Podstrekha, Director of the Financial Monitoring and Currency Control Department of the Bank of Russia Ilya Yasinsky, Deputy Chief of the Main Inspection of CO of the Bank of Russia Yelena Senchenko, Deputy Head of the Formation of the Lombard List Sector of the Summery and Economic Department of the Bank of Russia Kirill Tolchin.

As the moderators of the sessions acted President of the Association of Russian Banks Garegin Tosunyan, executive vice presidents of ARB Yuri Kormosh and Vladimir Kiyevsky. In one's speech Garegin Tosunyan stressed that such annual meetings are the important part of the strategic cooperation of the Association of Russian Banks and the bank of Russia. They have 
exclusive meaningful character and their importance to the bankers community and management of the Central Bank is evident.

The Association of Russian banks thanked Chairperson of the Central Bank of Russia Elvira Nabibullina for holding the meeting of the management of the Central bank with the banking community, as well as highlighted the positive rope of participating in the annual event of ARB Chairperson of the State Duma on the Financial Market Natalya Burykina and representatives of the Bank of Russia.

On 7 November 2013, President of the Association of Russian Banks G.A.Tosunyan in his speech at the meeting of heads of the banks with the management of the Bank of Russia noted that the Russian banking community must build its activities strategy in accordance with the state program on the development of the banking sector: '... Being the banking community we can and must become the co-participants of the process of developing such new approaches. The Association is working on its strategy, which must be improved taking into account the new requirements imposed to the credit organizations. And I think that our strategy will correspond to both the strategy of the Central Bank, its new standards and, respectively, the interests of all market participants' [14. P. 2].

Due to the conducted by ARB large-scale work on preparing the complex of R\&D and expert materials on the development and improvement of the financial sector in present-day Russia, the backbones of the long-term Strategy of promoting the Russian banking sector has been developed. On 5 April 2006, the XVII Assembly of the Association of Russian Banks adopted the National Banking System of Russia for 2010-2020 Program.

The National Banking System of Russia for 2010-2020 Development Program defines the quantitative and qualitative growth parameters of the native system of the credit organizations both for the medium and long terms, as well as formulates a set of measures necessary to achieve the goal. At the same time, the Program presents the interests not only of the banking community: it is strategically oriented on solving both economic issues of the country as a whole and social issues of each citizen of Russia: a businessman, pensioner, agricultural entrepreneur, scientist, student, etc. Thus, the implementation of the set by the Program goals is in the context of the implementation of the general aim of the macroeconomic development of Russia.

A significant innovation in the banking business sphere has become the implementation of the EvaBeta Russia\&cis program supported by ARB, which promotes the development of new opportunities for investors and managers while evaluating the quality of assets, which they have and manage. EvaBeta is an independent company having the cutting-edge technologies for evaluating and managing the risks. It offers the Russian commercial structures the specialized innovative technologies and methods of measuring and evaluating both financial and non-financial business-risks, which contributes to the improvement of the Russian financial market and increase of its qualitative and quantitative characteristics.

In March 2005, on the initiative of the Association of Russian Banks on the basis of the Federal Law on the credit histories, the National Bureau of Credit Histories JSC (NBCS JSC) being the present-day leader in the Russian financial market was established. Under the order of the Federal service on the financial markets No. 06-341/пз-и dated 21.02.2006 NBCS JSC was included into the national registry of credit history bureau; the registered capital of NBCS JSC is equal to 126 bln rubles. The base of the credit histories of individuals and legal entities of NBCS, developed as the result of cooperation with more than 6000 companies from all Russia's regions, is much bigger than the similar indicators of the rest credit bureaus rolled into one. NBCS is working with all 10 leading banks of the country, as well as other credit organizations having the high banking rate.

The business style of NBCS JSC has the high-level management, desire to promote meaningful partnership relations, conduct joint search of solving the issues of technological development of business processes. The partners of NBCS JSC are TransUnion (USA), CRIF (Italy) и Fair Isaac (USA) being the world leaders in the development of information solutions, which provide the clients with the most advanced and agreed offers. Due to the long-term cooperation with the given organizations, NBCS is ahead of other Russian credit bureaus on the quality of the provided services corresponding to the highest world standards.

In the context of the ARB projects aimed at developing and structuring Russia's banking world, establishing the positive business environment of the financial community, the National 
Banking Club providing the conduct of meetings of interests, establishment of new business ties, performance of business-projects presentations, etc, was established in 2008. At the same time, the action plan of NBC includes the conduct of cultural events: gala concerts, sports competitions, corporate and family VIP-tourism, personal assistants help and so on.

ARB acted as one of the initiators of developing in 1991 SB AMULET LLC having become one of the leading companies providing the professional security services to the Russian banking community.

Within the framework of the innovative projects of ARB, the National Payment Council was established. It is aimed at joining the participants of the native market of payment services and increasing the effectiveness of making payments via the implementation of the latest world practices and adoption of the cutting-edge financial technologies.

The perspective project of ARB has become the establishment of the Institute of Bankers on its initiative in 1996. To date the Institute of Bankers has become the leader in the sphere of providing the banking educational services. Its activities have been internationally recognized. IB was included as the full-fledged member into the European Bank Training Network (EBTN) [15].

The Association of Russian Banks stands for extending the interbank partnership at the world level considers it reasonable to develop the high-quality banking structures in the Russian Federation, particularly - the International Financial Center in Moscow [16. P. 18-24].

On 22 October 2013, President of ARB G.A.Tosunyan in cooperation with the Italian business partners headed by chief of the Italian tax service (the Internal Revenue Service of the Italian Republic) Attilio Befer met with Chairperson of the Bank of Russia Elvira Nabibullina. At the meeting, head of ARB submitted for approval of the management of the Central Bank of the Russian Federation the new joint Russia-Italy project developed in cooperation with the ARB and SOSE company specialists - the implementation of the Automated system of evaluating the financial state of the small and medium businesses into the Russian banking system to provide the opportunity of increasing the banks' trust to SMC and simplifying the development of credit factories for the small and medium businesses, thus contributing to the decrease of the interest rates on credits [17]. The management of the Central bank expressed the readiness to consider the results of piloting the adopted for the Russian financial market version of the program on the implementation of the given system into the Russian banks. They also noted that in present-day situation the issues of managing the risks connected with the re-funding of the banks portfolios, formulated on the credits of small and medium companies are very topical [17].

The following participants took part in the talks: First Deputy Chairperson of the Central Bank Alexey Simanovsky, Deputy Chairperson of the Central Bank Nadezhda Ivanova, Deputy Director of the Internal Revenue Service of Italy Marco Di Kapua, President of SOSE Dzhnpietro Brunello, President of EvaBeta Edoardo Narduzzi, Chairperson of the Board of Directors of the Inteza Bank Antonio Fallico, Chairperson of the Board of Directors of EvaBeta Alexander Gorin, Chairperson of the Board of Directors of the Uniastrum Bank Georgy Piskov, Chief of the Atlantic Department of ARB Sergey Grigoryan [17].

The Association of Russian Banks in cooperation with the ARB-TV Banking TV company established the channel on financial literacy aimed at increasing the level of financial literacy and awareness of people about the types of financial service, possibilities of getting the credit, technologies of the banking services. The PhingramTV contributes to the increase of the business and economic activeness of the Russians, intensifies the exchange of business information between the regions, and promotes the adoption of social liability principles of the native credit and financial establishments.

The effective project of ARB has become the development of the PriceFree national discount system introducing instead of the multiple club discount cards the only banking card Visa or MasterCard by PriceFree giving the right to get discounts and any other benefits for services in the hotels, restaurants, beauty salons, showrooms, malls, clubs, etc. The project has a wide geographical coverage: Moscow, St. Petersburg, Perm, Rostov-on-Don, Samara, Novosibirsk and other Russia's cities.

The Association of Russian Banks actively develops the interbank business cooperation via the institute of agency relations contributing to the signing of agreements between the large and medium capital and regional banks having the financially stable regional credit organizations in the context of promoting the latest banking products and programs to the regions on the commission 
basis. ARB supports the development of a new direction - search of business-partners by the credit organizations, as well as development of interbank partnership within the framework of the MP Interbank Payment System (IPS) program. The implementation of the given program will give the opportunity to the Moscow banks to disperse the financial flows on the territory of Russia and provide the regions with the wide-spectrum banking services. As the result of implementing the given project of ARB and activities of the institute of agency relations, the regional banks get the opportunity to adopt new technologies, preserve financial self-sufficiency and consistently increase its resource base and capitalization.

The Association of Russian Banks participates in the implementation of the Fellowship Program named after A.A.Kozlov established jointly with the Central Bank of the Russian Federation and MDM-Bank. The Fellowship was conceived as a reward for talented students of economic departments of the native universities, who showed excellent knowledge in finances and banking. The ARB Charity project presupposes the provision of the support by the banking community to the people in a difficult situation and those in need.

In 2013, the Association of Russian banks in cooperation with the All-Russian quality organization started to implement the best banks of Russia program in accordance with the general project of ARB President G.A.Tosunyan and AQO President N.P.Voronin.

The management of ARB pays significant attention to the development of the interbank business-cooperation aimed at presenting and coordinating the business interests in the relationships between the banks-partners, as well as relations between the banking business structures and non-banking sector organizations, which provide service support to the credit organizations: the Agency for promoting credit activities, National bureau of credit histories, Arbitration Court, Amulet security service, VEK legal advisory board, etc. On 7 October 2012, during the $1^{\text {st }}$ All-Russian Session of the banking associations the General agreement on consolidating the efforts of the banking associations on the development and strengthening the banking system of the Russian Federation, which is supported by 71 participants at present.

Within the framework of the initialized by ARB direction 'the interbank cooperation' the agency relations between the capital banks and regional financial organizations contributing to the promotion in Russia's regions of joint financial innovative programs, are developing. In the context of the ARB activities permanent meetings of the management of the Association and specialized committees with the representatives of the regional credit organizations are conducted: on 12 September 2003, Barnaul hosted the joint meeting of the Bureau of the banking associations of the Russian Federation and ARB Committee on the regional policy and interaction with the regional banking associations; on 21 June 2004, Khanty-Mansiysk hosted the joint meeting of the All-Russian council of the regional banking associations (the All-Russian banking council) and the Council of the Association of the credit organizations of the Tyumen region; on 22 June 2006, Vladimir hosted the joint meeting of the All-Russian banking council and ARB Committee on the regional policy. On 27-28 June 2012, Kaluga hosted the joint session of the All-Russian council of the regional banking associations, ARB Committee on the development of financial and credit mechanism of the small and medium businesses and ARB Committee on the regional policy. On 18 December 2012, Moscow hosted the joint meeting of the All-Russian banking council and ARB Committee on the development of financial and credit mechanism of the small and medium businesses.

The topical issued of developing the up-to-date banking system of Russia are considered at the sessions of the All-Russian banking council.

The corporate events, as well as scientific disputes, presentations of perspective financial development projects are conducted by the Club of heads of the banking services on public relations and advertising. On 16 October 2012, the office of the Association of Regional Banks of Russia hosted the meeting of the representatives of the Bankir.Ru agency and members of the Club of heads of the banking services on public relations and advertising

Vice President of the Association of Regional Banks of Russia and chief editor of the Bankir.Ru agency Yan Art said about the plans of developing Bankir.Ru and agency's services - the first financial photo bank in Russia, Bankir-TV project, Bankir.Ru - Ipocredit.ru - 123Credit.ru united center of on-line applications for credits. In addition, Yan Arts confirmed the readiness of Bankir.Ru to provide information and advertising support of the banks' charity on the noncommercial basis. 
The Associations of Regional Banks of Russia, State Duma Deputy Anatoly Aksakov urged the banks to participate in the PR-promotion of the common interests of the banking community more actively - lobbying for the laws promoting the effective development of the banking sphere, increasing financial literacy, developing the mutual understanding with the society and business [18].

Alexander Zagryadsky, head of the Club of heads of the banking services on public relations and advertising and Center of public relations of the Agency on the deposits insurance, stressed that the banking branch needs more effective communications with MMS, particularly, in the banking PR sphere [18]. Within the framework of the meeting, the presentation of the marketing researches the Key indicators of effectiveness of the specialist on public relations in the financial market: the peculiarity of the branch and topical tendencies has been conducted by the Vyazemsky Zaplsky communications bureau with the help of the Bankir.Ru agency [18].

ARB actively develops the international ties. In 1997, ARB became the member of the Banking Federation of the European Union as an associated member, thus significantly expending the possibilities of the Russian banks in the integration into the world financial space, contributing to the establishment of the communicative ties with the foreign banks. (The Banking federation of the European Union unites more than 3000 European banks).

Since 2010, ARB became the associated member of the International banking federation, which includes the leading banking entities of the European Union, USA, Canada, Australia, India, China, South Korea, Japan and SAR.

The activities of ARB played significant creative role in the development of the positive look of the Russian financial business world both in the corporate public opinion of the international community and the Russians - the potential clients of the developing innovative national banking system. Последовательная деятельность The consistent measures of ARB have contributed to integration of the Russian banking business to the world economic and legal space, development of the positive innovative climate in Russia, implementation of the international quality standards of the banking activities. During the whole period of its operation, ARB has been conducting the meaningful, multi-axes activities on the development of the credit policy and improvement of the financial state in the country; due to a number of ARB initiatives the national banking business implements the latest technologies and methods of financial activities.

ARB has been playing significant organizational and expert-advisory role in overcoming the financial crises of 1998, 2004 and 2008-2009. At present, ARB in cooperation with the institutes of political departments of the Russian Federation conducts creative policy of the development and improvement of the banking business [19. P. 2].

Within the framework of the specialized ARB Committee, the documents on the Basel III standard and risks management were developed, particularly, on the validity, technique of reasonable modeling (stress-testing), general issues of organizing the internal evaluating of the capital sufficiency [20].

The expending of the interaction of the Russian business community with the foreign financial partners, conducted due to the consistent policy of ARB, both opens the new perspectives of integrating the Russian banking capital into the world financial space and provides the flow of the foreign investments into the native economy.

Being the corporate organization of the native financial business, ARB acted as a significant system-building factor of the development of the new banking business-culture, which includes both the innovative technological methods of credit and financial activities and the new business culture based on the world standards of business ethics [21. P. 4].

On the initiative of ARB and personally its President G.A.Tosunyan, the Code of Banking Ethics has been developed and adopted. It became the act of self-regulation of the activities of the banking community in Russia on the basis of the business ethics principles, It also became an integral part of the unified system of the legal and moral and ethical provision of work of the native credit organizations. Particularly, the Code states: 'The credit organizations of the Russian Federation realize that the development of the native banking system, increase of its prestige in the society and role in solving the economic issues, effectiveness and culture of the banking business are depending on the activities of each credit organization, which makes necessary the full-scale usage for achieving the set goals of ethical norms and principles as one of the leading, along with the rule of law, means of self-regulation of the activities of the Russian business community' [22. P. 1]. 
Within the framework of developing in present-day Russia the business consciousness, the management of the business community defines the following principles of the business ethics:

'The credit organizations conduct their professional duties on the following basis:

- understanding of their civic and professional duty before the individuals and legal entities, society and state;

- recognizing the equality of the participants of the civil turnover involved in the sphere of the banking business, respecting their rights and legitimate interests;

- strengthening the interaction in the banking community, full-scale increase of the role of the association and other entities of the credit organizations in protecting the rights and legitimate interests of the banking community and its single members;

- maximal transparency of their professional duties with the absolute reliability in protecting the confidentiality of the information and date covered by bank secrecy;

- improving the corporate management and mutual control for the conscientiousness of the participants of the banking services market;

- unconditional compliance with their obligations and guarantee of the high-quality services provided;

- providing reasonable risking of the conducted operations;

- completeness of liabilities for the quality and results of their work;

- fair competition, active countermeasure to the unconscious participants of the banking activities, disclosure of the facts of violating the Code's provisions by procedures defined by the Commission on the control for complying with the Code's provisions;

- active participation in counter measuring of legalizing (laundering) the revenue gotten due to the criminal actions, terrorism financing and other illegal activities in the banking business sphere;

- refusing the voluntary cooperation with the legal entities and individuals with unsavory business reputation отказа;

- establishment and development of the international professional ties on the basis of mutual respect, mutual help and mutually beneficial cooperation' [22. P. 7].

During the whole period of 1990-2014, the activities of ARB were focused on the development in Russia of the new business culture in the sphere of the banking business, which includes the adoption of the principles of mutual trust between the participants of the native financial market, expand of the business cooperation among heads of the credit organizations and specialists of the banking sector, increase of prestige of the banking establishments, development of the information exchange within the financial world and etc. Since 2205, ARB focuses its attention on the implementation into the native banking business and real sector of economy of the high-tech knowledge-intensive industries, as well as venture capital. A significant attention is paid by ARB to the establishment of the information support of the banking business. The Association edits the printed body - the Bulletin of the Association of Russian Banks (is published 2 times a month) which is sent to its participants. The Bulletin of ARB publishes the materials covering the activities of the Association of Russian Banks: assemblies' documents, minutes of sessions of the Council and Presidium of ARB, information on the participation of the representatives of the banking community in the parliamentary hearings and meetings of the committees of the State Duma, Federal Assembly of the Russian Federation, meetings and talks with heads of the legislative and executive authorities of Russia, foreign guests and business partners, texts of the signed agreements and contracts, etc. The Bulletin of ARB publishes separate editions as the appendixes, which are sent to the Association's members, as well as thematic collections of various profiles, specialized magazines and newspapers, advertising materials, etc.

ARB publishes scientific journals, brochures, handbooks and training manuals that contain valuable methodological information for bankers, auditors and other professionals of the financial sector. The Association of Russian Banks offers its participants the opportunity to use the publishing activities for creating their business image, as well as offers a variety of options for participating in such publishing projects.

The information support to the participants of the Association and all the specialists in the field of the banking business is provided by the Banks and Technology specialized magazine edited by ARB. 
In 2004, on the initiative of ARB the National Banking Journal (NBJ), which has become the leading edition of the Russian financial and credit branch, was established. The establishment of NBJ has been defined by the internal needs of further development of the national financial and credit system, as well as need for improving the banking legislation, implementing the new principles of control over the credit organizations by the Central Bank, tasks of transiting to the international financial reporting standards, etc.

The Association publishes the Annual Reports on its activities containing the materials of the Assemblies of ARB, general date: the GDP dynamics, macroeconomic indicators, results of the development of the financial sector and others. The Annual Reports of ARB also analyze the results of foreign and regional activities of the Association, implementation of new technologies in the banking activities, the working results of the ARB experts in the legal field.

The corporate public organization of the Russian financial community the Association of Russian Banks contributes to the extending of the sphere of influence of the banking system in the social space - ARB has become a significant factor of establishing the civil society contributing to the implementation of a number of the social development programs, and others.

One of the most important directions of the expert activities of ARB is the R\&D and legislative work on preparing the draft legislative and normative acts, making amendments to the legislation in force and others. ARB takes expert and organizational efforts to gain the approval of the given projects by the Russian Federation Government, State Duma of the Russian Federation, Bank of Russia and other structures of the state executive and legislative authorities, bodies of managing and controlling the banking activities.

$\mathrm{ARB}$ conducts sufficient work on the development and improvement of the tax legislation. Within the framework of $\mathrm{ARB}$, the specialists on the international financial law render legal assistance to the native banking structures and credit organizations with involving both the native and foreign experience in the given sphere, which contributes to the enhancement of the general legal culture of the banking community.

Within the framework of ARB, a significant R\&D work on the development in Russia of the financial market, institutionalization of the banking system, development of the legal basis of investments and others are conducted. The important direction of activities of ARB is the conduct of expert evaluation of the perspective innovative economic projects, social models and investment programs. It is also involved in providing its members with advisory services, expert supporting of the perspective innovative projects, conducting $R \& D$ work in the sphere of the banking business.

The information and analytical assistance provided by the ARB specialists to the native banking structures contributes to the increase of the Russian banking system transparency, general improvement of the banking management.

In 2010, on the initiative of ARB the $1^{\text {st }}$ in the Russian Federation institute of financial ombudsman was established [11. P. 12]. Due to the active support of ARB the National Currency Association and National Association on the Payment Cards have been established in Russia.

ARB regularly organizes and conducts conferences, seminars, symposiums and exhibitions devoted to the topical issues of the monetary policy and banking activities, where there is an exchange of experience between heads of financial institutions, specialists and experts in the field of the banking business, scientists, economists, technologists in the field of information programs and others. On 19 August 2009, Smolensk hosted the joint meeting of the All-Russian banking council, ARB Committee on the regional policy and business community of the Smolensk region. The participants of the session exchanged their opinions on the prospects of the development of the financial and economic situation both in the central area of Russia and in the regions: the participants discussed the state of the financial and banking segment of economy, prospects of the banking business diversification, development of the innovative financial technologies [23. P. 235236].

On 18 June 2012, headed by Chairperson of the European trust Bank A.Krysin the session of the ARB Committee on the mortgage crediting was held. The participants discussed the topical issues of the mortgage market development under the present-day social and economic conditions.

The representatives of the Ministry of Economic Development of the Russian Federation, Sberbank of Russia, VTB 24, VTB Kapital, Rosbank, Bank of housing financing, GPB-Ipoteka, Vostochny Express Bank, FORA-Bank, URALSIB, Vozrozhdeniye Bank, Deltakredit Bank, Rosselkhozbank, Investtorgbank, Avtogradbank, Association of the mortgage companies, Samara 
Regional Fund of the housing and mortgage etc. took part in the discussion. The meeting was also attended by the representatives of AHML: Chairperson of the Supervisory Council Ilya LomakinRumyantsev, Deputy Director General Andrey Semenyuk, Executive Director oo Finances Natalya Koltsova, Director of information policy department Viktor Kochetkov, Director of the legal department Anna Volkova, and Chief of Staff of the Supervisory Council Irina Yegorova.

On 19 December 2013, the Arbat cultural center hosted the IX Award Ceremony by the Golden Lion National Banking Award conducted by ARB.

A significant role for the improvement of the present-day banking management has the qualified methodical assistance rendered by the ARB specialists to the native financial organizations.

ARB conducts the organizational and scientific and expert support of the banking structures (both of the state-controlled banks and privet commercial establishments) within the consolidation of the financial resources, development of the investment strategy and implementation of the innovative development programs.

\section{Conclusions}

So, one can conclude that since its establishment and till present times the Association of Russian Banks takes active and qualified participation in the development of the Russian banking business, effectively contributes to the enhancement of its quality standards.

Due to the meaningful activities of ARB, there is the extending of the business cooperation of the Russian financial and credit organizations with the foreign banks and international financial corporate organizations - associations and entities.

The consistent and creative activities of the Association of the Russian Banks promotes the development of the highly effective innovative national banking system, which is a significant organizational and intellectual contribution to the rise of the Russian economy till the level of the leading industrial countries of the world.

\section{References:}

1. Послание Президента России В.В. Путина Федеральному собранию Российской Федерации. 12 декабря 2013 г. М., 2013. С. 4.

2. Президент России В.В. Путин намерен усилить потенциал национальной банковской системы, институтов развития, фондового рынка. 11 апреля 2012 г. // http://itartass.com/arhiv/542866

3. Развитие банковской системы в России стало главной темой Совещания, которое провел Премьер-министр РФ Дмитрий Медведев. 28 ноября 2013 г. // Экономика. Финансы. // http://www.1tv.ru/news/crime/247197

4. Тихонков К.С. Стратегия развития банковской системы России: современные тенденции, мировой опыт, направления модернизации. М., 2012. С. 5

5. Дынников Е.А. Институциональные особенности обеспечения устойчивости банковской системы России // Экономика и гуманитарные науки. = Econ. science a. humanities. 2012. №1. C. 87.

6. Материалы XXIV Съезда Ассоциации российских банков (АРБ): «Банки и общество: роль кредитных организаций в социально-экономическом развитии России». 3 апреля 2013 г, Москва, Колонный зал Дома Союзов, M., 2013 // http://arb.ru/arb/management/congresses/4374425/

7. XXV Съезд Ассоциации российских банков, основной темой которого стало обсуждение проекта «О перспективах банковской системы России: взгляд банковского сообщества».// http://akorb.ru/news/informatsiya/2014/o3/o6/XXV_arb

8. Турович Л.И. Эволюция российской банковской системы и государственное регулирование ее деятельности. Смоленск, 2012.

9. Черникова Е.В. Регулирование банковской деятельности в Российской Федерации: административный и организационный аспекты. М., 2009. С. 25.

10. Вестник Ассоциации российских банков. Январь 2014. №1-2. С. 15.

11. Тосунян Г.А. Банковское дело и банковское законодательство в России: опыт, проблемы, перспективы. М., 1995. С. 227-228. 
12. Национальная платежная система и роль Банка России в ее развитии. Всероссийское совещание: Сборник докладов / Центральный банк Российской Федерации. M., 2012.

13. Встреча банкиров с Председателем Банка России Эльвирой Набиуллиной. // Вестник Ассоциации российских банков. Январь 2014 г. №1-2.

14. Выступление Президента Ассоциации российских банков Г.А. Тосуняна на встрече руководителей банков с руководством Банка России 7 ноября 2013 г. // Стенограмма. І сессия. М., 2013, с. 2

15. Институт банковского дела Ассоциации российских банков (ИБД АРБ) // www.ebtn.eu

16. Грибанич В.М. Проблемы создания в России международного финансового центра // Вестник экономической интеграции. М., 2012. №2. С. 18-24.

17. Глава АРБ Г.Тосунян представил в Центральный банк России новый совместный российско-итальянский проект. 23.10.2013 г. // http://bankir.ru/novosti/s/glava-arbpredstavil-v-tsb-novyi-sovmestnyi-rossiisko-italyanskii-proekt-10057979/

18. Состоялась встреча Bankir.Ru и Клуба руководителей банковских служб связей с общественностью и рекламы. Анонсы и информация Bankir.Ru 16.10.2012 // http://bankir.ru/novosti/s/sostoyalas-vstrecha-bankir-ru-i-kluba-rukovoditelei-bankovskikhsluzhb-svyazei-s-obshchestvennostyu-i-reklamy-10029404

19. Обращение Ассоциации российских банков от 17 апреля 1994 г. №A-01/2-228 к Президенту Российской Федерации «О мерах по стабилизации финансового положения России». М., 1994. С. 2.

20. Новости АРБ: Опубликованы документы, разработанные в рамках Комитета АРБ по стандартам Базель III и управлению рисками. // https://arb.ru/arb/press-onarb/opublikovany_dokumenty_razrabotannye_v_ramkakh_komiteta_arb_po_standartam_bazel $-9752497 /$

21. Коробов Ю.И. Новое понимание банковской культуры // Финансы и кредит. М., 2012. №15. C. 4.

22. Кодекс этических принципов банковского дела. С. 1.

23. Турович Л.И. Эволюция российской банковской системы и государственное регулирование ее деятельности. Смоленск, 2012. С. 235-236.

\section{References:}

1. Poslanie Prezidenta Rossii V.V. Putina Federal'nomu sobraniyu Rossiiskoi Federatsii. 12 dekabrya 2013 g. M., 2013. s. 4.

2. Prezident Rossii V.V. Putin nameren usilit' potentsial natsional'noi bankovskoi sistemy, institutov razvitiya, fondovogo rynka. 11 aprelya $2012 \mathrm{~g}$. // http://itar-tass.com/arhiv/542866

3. Razvitie bankovskoi sistemy v Rossii stalo glavnoi temoi Soveshchaniya, kotoroe provel Prem'er-ministr RF Dmitrii Medvedev. 28 noyabrya 2013 g. // Ekonomika. Finansy. // http://www.1tv.ru/news/crime/247197

4. Tikhonkov K.S. Strategiya razvitiya bankovskoi sistemy Rossii: sovremennye tendentsii, mirovoi opyt, napravleniya modernizatsii. M., 2012. S. 5

5. Dynnikov E.A. Institutsional'nye osobennosti obespecheniya ustoichivosti bankovskoi sistemy Rossii // Ekonomika i gumanitarnye nauki. = Econ. science a. humanities. 2012. №1, s. 87

6. Materialy XXIV S"ezda Assotsiatsii rossiiskikh bankov (ARB): «Banki i obshchestvo: rol' kreditnykh organizatsii v sotsial'no-ekonomicheskom razvitii Rossii». 3 aprelya 2013 g, Moskva, Kolonnyi zal Doma Soyuzov, M., 2013 // http://arb.ru/arb/management/congresses/4374425/

7. XXV S"ezd Assotsiatsii rossiiskikh bankov, osnovnoi temoi kotorogo stalo obsuzhdenie proekta «O perspektivakh bankovskoi sistemy Rossii: vzglyad bankovskogo soobshchestva». // http://akorb.ru/news/informatsiya/2014/o3/o6/XXV_arb

8. Turovich L.I. Evolyutsiya rossiiskoi bankovskoi sistemy i gosudarstvennoe regulirovanie ee deyatel'nosti. Smolensk, 2012

9. Chernikova E.V. Regulirovanie bankovskoi deyatel'nosti v Rossiiskoi Federatsii: administrativnyi i organizatsionnyi aspekty. M., 2009. S. 25.

10. Vestnik Assotsiatsii rossiiskikh bankov. Yanvar' 2014. №1-2. S. 15. 
11. Tosunyan G.A. Bankovskoe delo i bankovskoe zakonodatel'stvo v Rossii: opyt, problemy, perspektivy. M., 1995. S. 227-228.

12. Natsional'naya platezhnaya sistema i rol' Banka Rossii v ee razvitii. Vserossiiskoe soveshchanie: Sbornik dokladov / Tsentral'nyi bank Rossiiskoi Federatsii. M., 2012.

13. Vstrecha bankirov s Predsedatelem Banka Rossii El'viroi Nabiullinoi. // Vestnik Assotsiatsii rossiiskikh bankov. Yanvar' 2014 g. №1-2.

14. Vystuplenie Prezidenta Assotsiatsii rossiiskikh bankov G.A. Tosunyana na vstreche rukovoditelei bankov s rukovodstvom Banka Rossii 7 noyabrya 2013 g. // Stenogramma. I sessiya. M., 2013, s. 2

15. Institut bankovskogo dela Assotsiatsii rossiiskikh bankov (IBD ARB) // www.ebtn.eu

16. Gribanich V.M. Problemy sozdaniya v Rossii mezhdunarodnogo finansovogo tsentra // Vestnik ekonomicheskoi integratsii. M., 2012. №2. S. 18-24.

17. Glava ARB G.Tosunyan predstavil v Tsentral'nyi bank Rossii novyi sovmestnyi rossiiskoital'yanskii proekt. 23.10.2013 g. // http://bankir.ru/novosti/s/glava-arb-predstavil-v-tsb-novyisovmestnyi-rossiisko-italyanskii-proekt-10057979/

18. Sostoyalas' vstrecha Bankir.Ru i Kluba rukovoditelei bankovskikh sluzhb svyazei s obshchestvennost'yu i reklamy. Anonsy i informatsiya Bankir.Ru 16.10.2012 // http://bankir.ru/novosti/s/sostoyalas-vstrecha-bankir-ru-i-kluba-rukovoditelei-bankovskikhsluzhb-svyazei-s-obshchestvennostyu-i-reklamy-10029404

19. Obrashchenie Assotsiatsii rossiiskikh bankov ot 17 aprelya $1994 \mathrm{~g}$. №A-01/2-228 k Prezidentu Rossiiskoi Federatsii «O merakh po stabilizatsii finansovogo polozheniya Rossii». M., 1994. S. 2.

20. Novosti ARB: Opublikovany dokumenty, razrabotannye v ramkakh Komiteta ARB po standartam Bazel' III i upravleniyu riskami. // https://arb.ru/arb/press-onarb/opublikovany_dokumenty_razrabotannye_v_ramkakh_komiteta_arb_po_standartam_bazel $-9752497 /$ S. 4 .

21. Korobov Yu.I. Novoe ponimanie bankovskoi kul'tury // Finansy i kredit. M., 2012. №15.

22. Kodeks eticheskikh printsipov bankovskogo dela. S. 1.

23. Turovich L.I. Evolyutsiya rossiiskoi bankovskoi sistemy i gosudarstvennoe regulirovanie ee deyatel'nosti. Smolensk, 2012. S. 235-236. 